\title{
Kemik enfeksiyonları ve tedavisinde gümüş iyon içeren nano-hidroksiapatit kullanımı
}

\author{
Bone infections and treatment of bone infections using silver-ion \\ containing nano-hydroxyapatite
}

\author{
Nusret Köse ${ }^{1}$, Aydan Ayşe Köse ${ }^{2}$, Ayşe Gül Toktaş3 ${ }^{3}$ Aydın Doğan ${ }^{3}$ \\ ${ }^{1}$ Eskişehir Osmangazi Üniversitesi Tıp Fakültesi, Ortopedi ve Travmatoloji Anabilim Dalı, Eskişehir \\ ${ }^{2}$ Eskişehir Osmangazi Üniversitesi Tıp Fakültesi, Plastik ve Rekonstrüktif Cerrahi Anabilim Dalı, Eskişehir \\ ${ }^{3}$ Eskişehir Teknik Üniversitesi, Malzeme Bilimi ve Mühendisliği Bölümü, Eskişehir
}

\begin{abstract}
Daha temiz cerrahi ortamlar, cerrahi girişim öncesi antibiyotik kullanımı ve cerrahi asepsi-antisepsi ameliyatlara bağlı enfeksiyon insidansını azaltmasına rağmen, implant ile ilişkili enfeksiyon görülme riski hala yüksektir. Tüm cerrahi prosedürlerden sonra yaygın bir komplikasyon olan cerrahi bölge enfeksiyonlarına genellikle cerrahi prosedür sırasında yaraya giren eksojen ve endojen mikroorganizmalar neden olur. Her türlü cerrahi prosedürle ilişkili potansiyel bir komplikasyondur. Sağlıkla ilişkili enfeksiyonlar içinde en önlenebilir olanlar arasındadır. Cerrahi bölge enfeksiyonları genellikle insizyon bölgesine lokalizedir, ancak kas-iskelet dokuları dahil daha derin yapılara uzanabilir. Ortopedik cerrahide, implantların (eklem protezi, intramedüller çivi, eksternal fiksatör vb.) uzun yıllar kullanılabilme durumu, esas olarak implantın kemiğe entegrasyonuna ve çevresindeki bölgelerde enfeksiyon olmamasına bağlıdır. Enfeksiyonlar için ideal antimikrobiyal ajan, vücutta sistemik toksisiteye neden olmadan yüksek lokal konsantrasyonlara ulaşabilmeli, kemik yenilenmesine ve biyolojik dokularla implant entegrasyonuna müdahale etmemelidir. İmplantla ilişkili enfeksiyonlar için çok yüksek dozlarda antibiyotik kullanılmasına rağmen, hedef bölgede nispeten daha düşük bir ilaç konsantrasyonu elde edilir ve başarı oranı yüksek değildir. İmplantla ilişkili enfeksiyonlar esas olarak implant yüzeyini doğrudan çevreleyen dokularda meydana geldiğinden, bu enfeksiyonları önlemek ve tedavi etmek için antimikrobiyalleri lokal olarak taşımak akıllıca olacaktır. Enfeksiyonların önlenmesi için mikropların implant yüzeyine yapışmasını önleyen yöntemler tercih edilir. Antibiyotik yüklü kaplamalarda görülebilecek yüksek antibiyotik direnci riski ve diğer problemler göz önüne alındığında, antibiyotik olmayan maddeler çok daha çekici bir alternatiftir. Çeşitli maddeler arasında gümüş iyonu, bakteriyel bağlanmayı önlediği için öne çıkan bir ajandır. Geniş antibakteriyel spektrumu (hem gram negatif hem de pozitif bakteri) uzun süreli antibakteriyel etkiye sahip olması ve direnç gelişimine daha az eğilimli olması avantajdır.
\end{abstract}

Anahtar sözcükler: nano-hidroksiapatit; gümüş; osteomiyelit

\begin{abstract}
Although the cleaner surgical environment, antibiotic use, and surgical asepsis-antisepsis have reduced the incidence of infections during surgery, the risk of implant-related infections is still high. Surgical site infections, a common complication after all surgical procedures, are usually caused by the exogenous and endogenous microorganisms that enter the wound during the surgical procedure. It is a potential complication associated with any type of procedure and are among the most preventable health careassociated infection. Surgical site infections are usually localized to the incision site, but may extend into deeper structures, including musculoskeletal tissues. In orthopedic surgery the ability of the implants (joint prosthesis, intramedullary nail, external fixator, etc.) to be used for many years depends mainly on the integration of the implant with the bone and no infection in the surrounding areas. The ideal antimicrobial agent for infections should be able to reach high local concentrations without causing systemic toxicity and should not interfere with bone regeneration and implant integration with biological tissues. Despite the use of very high doses of antibiotics for implant-related infections, a relatively lower drug concentration was achieved at the target site and the success rate was not high. Since implant-related infections occur mainly in the tissues directly surrounding the implant surface, it is wiser to transport antimicrobials locally to prevent and treat these infections. Methods that prevent microbes from adhering to the surface of the implant are preferred for the prevention of infections. Given the high risk of antibiotic resistance associated with antibiotic-loaded coatings and other problems, non-antibiotic substances are a much more attractive alternative. Among the various substances, silver ion is a substance that come forward because it prevents bacterial attachment, its broad antibacterial spectrum (both gram negative and positive bacteria) has a long-term antibacterial effect and is less prone to resistance development.
\end{abstract}

Key words: nano-hydroxyapatite; silver; bone infection

- Illetişim adresi: Prof. Dr. Nusret Köse, Eskişehir Osmangazi Üniversitesi Tıp Fakültesi, Ortopedi ve Travmatoloji Anabilim Dalı, Eskişehir Tel: 0555 - 3112091 e-posta: drnkose@gmail.com

- Geliș tarihi: 3 Haziran 2020 Kabul tarihi: 18 Haziran 2020 
ontaminasyon, organizmanın vücut dokularında bakteri, virüs, mantar ve parazit gibi mikroorganizmaların varlığı iken enfeksiyon, hastalığa neden olan, patojen olarak bilinen bu ajanların vücut dokularını istilası ve bunların çoğalması ile konakçı dokuların bu bulaşıcı ajanlar ve toksinlere karşı oluşturduğu reaksiyondur. Bir enfeksiyonun semptomları, mevcut mikroorganizmaya ve enfeksiyonun bulunduğu bölgeye bağlıdır. Bakteriyel enfeksiyonu olan bir kişi genellikle enfeksiyon bölgesinde ağrı, kızarıkıı, şişme, ateş ve ısı artışı yaşayacaktır. Enfeksiyon türleri çeşitlidir ve bunlar farklı şekillerde tedavi edilir. Bir hastada, bir hastanede veya sağlık kuruluşunda bakım sürecinde sağlık bakımı ile ilişkili ortaya çıkan ve başvuru sırasında olmayan enfeksiyon "nozokomiyal" olarak da bilinir. Taburcu olduktan sonra da sağlık bakımı ile ilişkili enfeksiyonlar ortaya çıkabilir. Enfeksiyon hasta ile ilişkili istenmeyen olayların en sık olanıdır. Yüz milyonlarca hasta her yıl dünya çapında sağlık bakımıyla ilişkili enfeksiyonlardan (SBIE) etkilenmektedir. Şu anda, hiçbir ülke SBIE'nin neden olduğu hastalık yükünden muaf değildir. Cerrahi alan enfeksiyonları (CAE) tüm cerrahi prosedürlerden sonra görülebilen yaygın bir komplikasyondur. Bu enfeksiyonlara genellikle cerrahi prosedür sırasında yaraya giren eksojen ve endojen mikroorganizmalar neden olur. Her türlü prosedürle ilişkili potansiyel bir komplikasyondur ve en önlenebilir SBIE arasındadır. Cerrahi işlem geçiren hastaların ortalama \%11'ini etkilediğinden, CAE düşük ve orta gelirli ülkelerde en sık görülen SBIE türüdür. Amerika Birleşik Devletleri Hastalık Kontrol ve Önleme Merkezleri (CDC), CAE'yi cerrahi işlemin 30 günü içinde veya protez materyali implante edilirse 90 gün içinde cerrahi insizyonda veya yakınında meydana gelen ameliyat prosedürüyle ilişkili enfeksiyon olarak tanımlayan kriterler geliştirmiştir. ${ }^{[1-3]}$

Uzun yıllar boyunca, tüm cerrahi yaraların derideki veya hastanın vücudundaki bakteriler tarafından kontamine olduğu ve çoğu kontaminasyonun klinik enfeksiyonlara dönüşmesini önleyen konakçı mekanizmaları olduğu bilinmektedir. Konakçı savunması, özellikle kontaminasyondan hemen sonra, yani erken ameliyat döneminde önemlidir. Bu faktörlerin yara enfeksiyonlarının gelişimi üzerinde etkisi vardır: 1) kontaminasyonun karakteri ve boyutu; 2) hemostaz, yabancı cisimler, hasarlı dokular vb.'nin yerel çevreye etkileri; 3) oksijen, enflamatuar hücreler, büyüme faktörleri, sitokinler ve besin bileşenleri gibi bağışıklık bileşenlerini sağlayan yara perfüzyonu; 4) antibiyotik uygulaması ve 5) bağışıklık fonksiyonu. [4]

Hastanın ameliyattan önce, ameliyat sırasında ve sonrasında karşılaştığı birçok faktörün CAE riskine katkıda bulunduğu gösterilmiştir. $\mathrm{Bu}$ nedenle, bu enfeksiyonların önlenmesi karmaşık bir süreçtir ve bir dizi önleyici tedbirin entegrasyonunu gerektirir. Enfeksiyonların önlenmesine yönelik son kanıtlardan 20 uzman tarafindan rafine edilen 29 öneri Dünya Sağlık Örgütü (DSÖ) tarafından listelenmiştir. Önerilerin 13'ü ameliyat öncesi, 16'sı ameliyat ve sonrası dönemi içermektedir. Panel, ortopedik cerrahi geçiren bir kişi eğer burnunda S.aureus taşıyıcısı ise, bu hastaların ameliyat dönemi intranazal mupirosin \%2 merhem almasını önerir. CHG (klorheksidin glukonat) vücut yıkaması da eklenebilir. Panel, ameliyat öncesi dönemde veya ameliyathanede kılların jilet ile tıraş edilmesini önermez. Herhangi bir cerrahi işlem geçirecek hastalarda epilasyon kesinlikle gerekliyse, bir traş makinesi kullanılabilir. Panel, cerrahi antibiyotik profilaksisinin cerrahi insizyondan önce uygulanmasını ve operasyonun tamamlanmasından sonra CAE'yi önlemek amacıyla uzatılmaması gerektiğini önermektedir. Panel, cerrahi el temizliğinin steril eldiven giyilmeden önce antimikrobiyal sabun ve su ile firçalanması veya alkol bazlı el sıvısı ile ovma şeklinde yapılması gerektiğini belirtmektedir. Hastaları banyoda yıkamak veya ameliyattan önce duş almak iyi bir uygulamadır. Bunun için basit bir sabun kullanılabilir. Özellikle klorheksidin glukonat (CHG) esaslı alkol bazlı antiseptik solüsyonlar, ameliyat edilen hastalarda cerrahi bölge cilt hazırlığı için önerilmektedir. Endotrakeal entübasyon ile genel anestezi uygulanan hastaların cerrahi sırasında ve mümkünse ameliyat sonrası $2-6$ saat boyunca oksijen soluması önerilir. ${ }^{[2]}$

CAE'ler genellikle insizyon bölgesinde lokalizedir, ancak kas-iskelet dokuları dahil daha derin yapılara uzanabilir. Son dönemlerde sanayileşme, askeri teknoloji ve uzay endüstrisindeki ilerlemeler ile ortopedi ve travmatoloji alanında uygulanan cerrahideki ilerlemeler hastaların artan beklentilerini karşılayabilmek adına kırıkların tespitinde, kaynamamaların iyileşmesinde, eklem protezlerinde ve omurga rekonstrüksiyonlarında daha çok implant kullanımını gündeme getirmişitr. Kronik kemik enfeksiyonları ortopedi ve travmatoloji alanında uygulanan cerrahinin en önemli sorunlarından biridir ve bu durum sadece gelişmiş toplumların sorunu değildir. \%1-50 arasında enfekte olabilen açık kırık olguları, implant ile ilişkili enfeksiyonlar ve diyabetik ayak ülseri olguları göz önüne alındığında, osteomiyelit tüm dünyada çok yaygın bir sorun olarak görülecektir. Bunun sonucu olarak tekrarlanan ameliyatlar, uzun süreli antibiyotik kullanımı ve yüksek maliyetler tüm toplumları etkilemektedir. ${ }^{[5]}$

Ortopedi ve travmatoloji alanında uygulanan cerrahide, vücut içine konan implantların (eklem protezi, intramedüller çivi, fiksatörler vb.) uzun yıllar hizmet edebilmesi, mekanik yüklenmelere ve korozyona karşı 


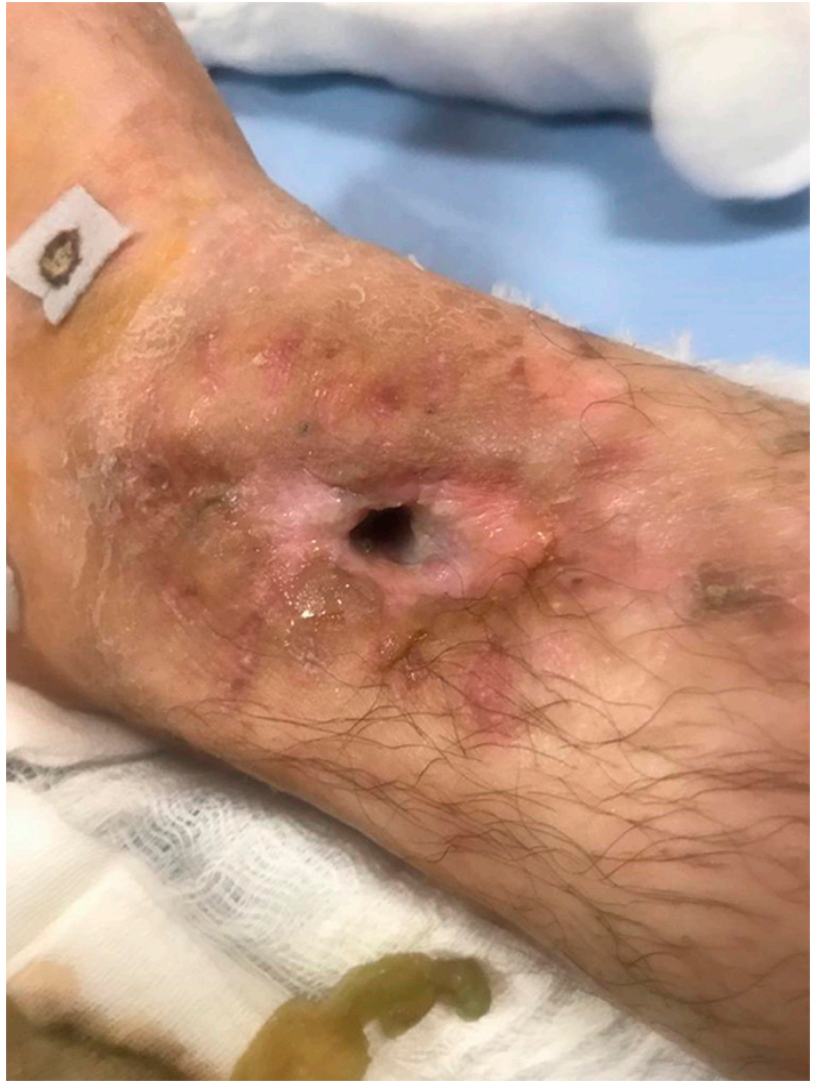

Şekil 1. Cerrahi alan enfeksiyonu olan hasta.

koyabilmesi yanısıra esas olarak implantın kemiğe entegrasyonuna ve implant çevresinde enfeksiyon olmamasına bağlıdır. Daha temiz cerrahi ortam, antibiyotik kullanımı ve cerrahi asepsi-antisepsi ameliyat sırasında enfeksiyon insidansını azaltmasına rağmen, implant ile ilişkili enfeksiyon riski hala yüksektir. Ayrıca, enfekte implantların görülme sıklığı, implant kullanım sayısındaki artış ve bu implantları olan hastaların yaşam süresinin uzaması nedeniyle geç ve hematojen enfeksiyon riskinin yükselmesi nedeniyle artmaktadır. İmplantla ilişkili enfeksiyonların insidansı bölgeye ve uygulamaya bağlı olarak değişebilir. Artroplastide olguların \%1-5'inde görülebilir, özellikle evre IIIC açık kırıklarında enfeksiyon insidansı \%50'ye kadar çıkabilir. ${ }^{[6]}$ Eksternal fiksatör uygulamalarında enfeksiyon insidansının \%11-96 olduğu bildirilmektedir. ${ }^{[7]}$

Enfeksiyon, implant ile ilişkili cerrahi prosedürlerde en korkulan ve sorunlu komplikasyondur. Implantla ilişkili enfeksiyonlar, kemik doku destrüksiyonu, implant yetmezliği, amputasyon ve hatta genel sepsise yol açabileceğinden hem hastalar hem de sağlık hizmeti sağlayıcıları için çok önemli bir sorundur (Şekil 1). Bu enfeksiyonlarda hekim, çoklu cerrahi müdahalenin gerekliliği, hastada uzun süreli sıkıntı ve kısıtlamalar ve nadiren istenmeyen sonuçlar ve daha yüksek mortalite olasılığı ile karşı karşıyadır. ${ }^{[8]}$ İmplantla ilişkili enfeksiyonların önlenmesi, bu komplikasyonun ortaya çımasıyla ilişkili ekonomik, sosyal ve psikolojik sorunlar nedeniyle yaşamsal önem taşımaktadır. ${ }^{[9]}$

Hastamızda oluşturduğumuz tüm cerrahi yaralar mikroplarla kontamine olur. Mikroplar virülansları ile hastanın savunma mekanizmalarının üstesinden gelirse, yara enfeksiyonu veya implant ile ilişkili enfeksiyon meydana gelecektir. Hastanın cerrahi ve çevresel faktörleri ile bağışıklık ile ilişkili faktörler enfeksiyonun klinik oluşumu için önemlidir. Diyabet, romatoid artrit, sigara içimi, bağışıklık baskılanan durumlar (steroid, kemoterapi), yetersiz beslenme, yaşılık, ameliyat öncesi hastanede yatış, obezite, vücutta enfeksiyon varlığı, ameliyat öncesi burnunda S.aureus kolonizasyonu cerrahi bölge enfeksiyonu için risklidir. Cerrahi yaralarda serbest yüzen planktonik bakteriler uygun sistemik antibiyotiklerle kolayca öldürülebilir. Bununla birlikte, bakteriler implant yüzeyine yapışır ve bir biyofilm tabakası oluşturursa direnç gelişir. Enfekte ortopedik implantlarda tespit edilen en yaygın mikroplar S.aureus ve S.epidermidis'tir. Bu bakteriler normalde cildimize zarar vermeden yaşarlar, ancak cerrahi yarayı istila ettiklerinde sorunlar başlar. Cerrahi yarayı istila eden bakteriler çoğalır, daha sonra bu mikroplar fiziksel ve kimyasal faktörler arasındaki etkileşim nedeniyle implantın yüzeyine ulaşır. İmplant bölgesindeki biyolojik dokulardaki proteinler, bu mikropların implant yüzeyine bağlanmasını kolaylaştırır. İmplant yüzeyinde birikmeye başlayan bakteriler, polisakkarit matris ve proteinlerin biyofilm tabakası ile çevrilidir. Yirmi dört saat içinde implant yüzeyinde tam bir biyofilm tabakası oluşabilir. Bu biyofilm tabakasındaki mikroplar yavaş yavaş çoğalır ve hücresel ve humoral bağışıklık sistemlerine direnir. Ek olarak, antibiyotiklerin penetrasyonunu önleyerek antibiyotiklere daha dirençli hale gelirler. MIC (minimal inhibitör konsantrasyon) değerleri 1000 kat artar. İmplant materyalleri üzerinde bakteriyel biyofilm oluşumu osteoliz ve implant gevşemesinin önde gelen nedenlerinden biridir. ${ }^{[10]}$

Enfeksiyonlar için ideal antimikrobiyal ajan, sistemik toksisiteye neden olmadan yüksek lokal konsantrasyonlara ulaşabilmeli ve bakterilerin sesil formlarına karşı etkili olmalı ve kemik yenilenmesine ve biyolojik dokularla implant entegrasyonuna müdahale etmemelidir. İmplantla ilişkili enfeksiyonlara klasik yaklaşım, hastaya sistemik antibiyotik uygulamasıdır. İmplantla ilişkili enfeksiyonlar için çok yüksek dozlarda antibiyotik kullanılmasına rağmen, hedef bölgede nispeten daha düşük bir ilaç konsantrasyonu elde 
edilir ve başarı oranı yüksek değildir. Ek olarak, bu kadar yüksek dozlarda verilen antibiyotiklerin toksik yan etkileri ortaya çıkar. İmplant ile ilişkili enfeksiyonlar esas olarak implant yüzeyini doğrudan çevreleyen dokularda meydana geldiğinden, bu enfeksiyonları önlemek ve tedavi etmek için antimikrobiyalleri lokal olarak bu bölgeye taşımak akıllıca olacaktır. ilk başta, Buchholz ve ark.[11], çimentolu protez uygulamalarında polimetilmetakrilat (PMMA) kemik çimentosuna antibiyotik ekleyerek lokal antibiyotik profilaksisini denemişlerdir. Bu amaçla spongiyöz kemik ve kollajen sünger gibi gözenekli malzemeler de kullanılmıştır. ${ }^{[12]}$ Bu yöntemlerin en büyük avantajı, sistemik uygulama olmadan implant çevresindeki belirli bir antimikrobiyal konsantrasyonuna erişebilmeleridir. Operasyon sırasında antimikrobiyal çözeltide kullanılan implantların daldırılmasının etkisi kontrolsüz, değişken ve çok kısa süreli iken, sözü edilen bu yöntemde kontrollü ve daha uzun süreli antibiyotik salınımı olabilmektedir. Klinik çalışmalar lokal antimikrobiyallerin kullanımının enfeksiyon komplikasyonlarını azaltmada kısmen etkili olabileceğini göstermiştir ancak bu yöntemin başarısı yeterli bulunamamıştır. Ayrıca tüm dünyada çimentodan kaynaklanan sorunlar nedeniyle çimentosuz protez uygulamalarına yönelik bir eğilim vardır.

Vücut içine uygulanan implanta biyolojik tepkinin nasıl olacağı implantın yüzey özelliklerine bağlıdır. İmplant yüzeyi ve çevresindeki dokular ve vücut sıvıları aktif bir ortam oluşturur. Biyomalzemelerin yüzey modifikasyonları ve yüzey kaplamaları, implantların doku ile etkileşiminin geliştirilmesinde anahtar rol oynar. Ortopedik implantlar, kemik dokusu ile osseo-entegrasyonu teşvik ederken bakterilerin yapışmasını ve kolonizasyonunu önlemesi istenir. Ancak, bu iki beklenti çelişkili süreçlerdir. Çünkü kemik dokusu hücrelerinin yapışmasını, ilerlemesini ve büyümesini (osseo-entegrasyon) artıran malzeme yüzeyleri, bu hücrelerle benzer bağlantı mekanizmalarına sahip mikroorganizmalar için pozitif özelliklerdir. ${ }^{[13,14]}$ Diğer yandan, bakteri kolonizasyonu ve biyofilm oluşumunu önleyen yüzeyler ve kaplamalar, kemik dokusu ile istenen osseo-entegrasyonu göstermeyebilir. Sonuç olarak, bu sorunun çözümü, kemik dokusu ile uyumluluğu bozmayan özelliklere sahip yeni enfeksiyona dayanıklı kaplamalar geliştirmeye bağlı olacaktır.

İmplantla ilişkili enfeksiyonlarda osteoliz ve implant gevşemesine neden olan lokal progresif doku yıkımının ana nedeni, implant yüzeyinde bakteriyel biyofilm tabakasının oluşması ile başlar. Bu enfeksiyonların önlenmesi ve tedavisindeki güncel bilimsel çalışmalar, bakterilerin implant yüzeylerine yapışmasını engelleyecek ve böylece biyofilm tabakasının oluşumunu önleyecek koruyucu yöntemlerin geliştirilmesine odaklanmıştır. ${ }^{[15]}$ Günümüzde implant ile ilişkili enfeksiyonları azaltmak ve önlemek için iki strateji kullanılmaktadır. Birincisi, bakterilerin implanta yapışmasını azaltmak veya önlemek için implant yüzey özelliklerinin modifikasyonudur (pasif kaplama). Pasif kaplama bakterisidal ajanları çevreye salmaz. Bu kaplama bakteriyel yapışmayı önler. İkincisi, antimikrobiyal ajan ile kaplanan implant tarafından implant yüzeyine ulaşan bakterilerin aktif olarak öldürülmesidir (aktif kaplama). İmplantın yüzeyi antimikrobiyal ajanla ya da implantın yüzeyinde antibiyotik ajanların salınmasına izin veren bir tabaka ile kaplanır ya da implant çevresine antimikrobiyal ajan salgılayarak bakterileri öldürecek lokal bir alan oluşturacak bir materyalden yapılır.

Mikropların implant yüzeyine yapışmasını önleyen yöntemler, aktif antimikrobiyal ajanlara ihtiyaç duyulmaması, implantasyon bölgesi üzerinde olumsuz bir etkiye sahip olacak farmakolojik potansiyelin olmaması ve negatif antibiyotik direncinin olmaması nedeniyle enfeksiyonun önlenmesi için tercih edilir. Ancak mikropların implant yüzeyine yapışmasını önleyen yöntemler ile ilgili olarak; Her birinin farklı yüzey bağlanma aktivitesine sahip olduğu ve çoğu zaman bakteri adhezyonunu desteklediği bilinen 20.000'den fazla sayıda farklı proteinlerin, mililitrede $70 \mathrm{mg}$ yoğunlukta olduğu doku ortamında etkili olabilmesi gerekmektedir. Ayrıca bu yüzey yapışmasını önleyen etki implant vücutta kaldığı sürece sürmeli, implantın sterilizasyonundan ve cerrahi manipülasyonundan olumsuz etkilenmemeli, hastada immun ve enflamatuvar hücre yanıtları oluşturmamalı ve in vitro olduğu gösterilen antimikrobiyal etkinin klinik kullanımda in vivo da etkili olması gerekmektedir. Sonuçta, bakteriyel yapışmayı azaltmak için uygulanan pasif kaplamaların etkinliği sınırlıdır ve büyük ölçüde bakteri türlerine bağlı olarak değişir ya da çok maliyetlidir. ${ }^{[16,17]}$

Kemik doku ağırlığının yaklaşık \%50'sini oluşturan inorganik mineral fazı hidroksiapatittir. Birçok çalışmada metalik implantların yüzeylerinin hidroksiapatit (HA) ile kaplanarak kemik ile osseo-entegrasyonu artırdığı gösterildiğinden günümüzde metalik implantların biyolojik özelliklerini geliştirmek için sıklıkla kalsiyum fosfat seramikleri kullanılmaktadır. ${ }^{[18]}$ Son yıllarda HA kaplamaları sadece osseo-entegrasyonu artırmak için değil aynı zamanda büyüme faktörleri, biyoaktif moleküller ve DNA'yı taşıma amacı için de kullanılmaktadır. ${ }^{[19,20]}$ Hidroksiapatit, kalsiyum fosfat seramiğinin kristalin bir formudur ve ortam sıcaklığında 4-12 pH aralığında en kararlı kalsiyum fosfat seramiğidir. HA'nın kristal yapısı P63/m uzay grubu ve altıgen yapıdır. Hidroksiapatitin parçacık boyutu osseo-entegrasyon için önemli bir parametredir. Nano ölçekli HA'nın osseo-entegrasyonu artırdığı 
bildirilmiştir. Şimdiye kadar, implant yüzeyinde hidroksiapatit kaplamak için birçok teknik kullanılmıştır. Bu kaplama teknikleri sol-jel, elektroforetik biriktirme, püskürtme, elektro sprey, daldırma kaplama, spin kaplama, sprey kaplama ve plazma spreyidir..21] Bir sonraki mantıksal adım, bu yüzeylere antimikrobiyallerin eklenmesi idi. Böylece implant yüzeyinde bakteri kolonizasyonu önlenecek ve enfeksiyon için nidüs bölgesinde yüksek konsantrasyonda antibiyotik sağlanacaktır. Gözenekli hidroksiapatit (HA) kaplı titanyum implantlara gentamisin, vankomisin ve benzeri antibiyotikler uygulanmıştır. ${ }^{[22]}$ Bununla birlikte, bu yöntemde optimal salım kinetiği ve antibiyotik metodolojisi ile ilgili problemler hala çözülmemiştir. Bunun dışında HA seramiklerin kaplanma işlemi sırasında gereken yüksek sıcaklık nedeniyle, birçok antibiyotikle ilgili sorunlar vardır. Sonuç olarak, hidroksiapatit seramiklerine antibiyotik ilavesi istenildiği kadar başarılı olmamıştır. Belki de bunlardan daha önemlisi antibiyotiklere karşı direnç gelişimi gösteren mikropların giderek artması sorunudur.

\section{ANTIMIKROBIYAL OLARAK GÜMÜŞ IYONU}

Antibiyotik yüklü kaplamalarla ilişkili olarak yüksek antibiyotik direnci riski ve diğer sorunlar göz önüne alındığında, antibiyotik olmayan maddeler çok daha çekici bir alternatiftir. Çeşitli maddeler arasında gümüş, bakteriyel bağlanmayı önlediği için öne çıkan bir maddedir. Geniş antibakteriyel spektrumu (hem gram negatif hem de pozitif bakteri) uzun süreli antibakteriyel etkiye sahiptir ve direnç gelişimine daha az eğilimlidir. Ayrıca, gümüşün yüzeylere kolayca uygulanabileceği stabil kaplamalar elde etmek için çeşitli teknikler geliştirilmiştir. ${ }^{[23]}$ Gümüş hidroksiapatit gibi biyoaktif yüzey malzemeleri ile birlikte kullanılırsa, yüksek osseo-entegrasyon ve antimikrobiyal aktiviteye sahip bir implant elde ederiz.

Gümüşün antimikrobiyal etkisi eski zamanlardan beri bilinmektedir. Geniş antimikrobiyal etkisi ve düşük yan etkisi ile kaplama için uygun bir metaldir. Gümüş iyonunun $\left(\mathrm{Ag}^{+}\right)$antibakteriyel özelliği metalden $(\mathrm{Ag})$ çok daha etkilidir. Bakteriyel DNA'ya bağlanır, fosfat ve süksinat alımı gibi birçok önemli taşıma yolunu inhibe eder ve hücresel oksidasyonu bozar. Hücre zarını ve içeriğini bozar. Bakteriler, mantarlar ve virüsler üzerinde de etkilidir. Damarsal katater, idrar kateteri, peritoneal kateter, vasküler greftler, kalp kapak protezleri, sütürler ve kırık tespit implantları gibi birçok tıbbi implant yüzeyine uygulanmıştır. ${ }^{[24]} \mathrm{Hem}$ literatür çalışmalarında hem de bizim önceki araştırmalarımızda hayvan çalışmalarında gümüş kaplı protezlerin ve implant uygulamalarının enfeksiyon olasıIığını azalttığı gösterilmiştir. ${ }^{[25-28]}$ Titanyum üzerine uygulanan gümüş içeren HA kaplamaların, osteoblast ve epitel hücrelerinin aktivitesini bozmadan bakteriyel yapışmayı ve proliferasyonu etkili bir şekilde inhibe edebildiği gösterilmiştir. ${ }^{[23,29]}$ Gümüş kaplı titanyum vidaların implantla ilişkili derin kemik enfeksiyonlarını önlediği gösterilmiştir. ${ }^{[30,31]}$ Literatürde, bazı yazarlar başarılı in vitro sonuçlara rağmen, bazı çalışmaların gümüş kaplı tıbbi implantlarla enfeksiyonda klinik başarı göstermediğini bildirmektedir. ${ }^{[26,28]}$ Gümüş kaplı implant yüzeylerinden yetersiz gümüş salınımı veya hiç salınamaması ve potansiyel gümüş toksisitesi gibi kısıtlılıkların literatürde var olan bu gibi çelişkili sonuçlara neden olabileceği değerlendirilmektedir.

Literatürde gümüş kaplı protezlerle yapılan deneysel hayvan çalışmalarının olumlu sonuçlarından sonra seçilen hastalarda gümüş implantlar kullanılmıştır. Hardes ve ark. ${ }^{[32]}$, gümüş kaplı megaprotez kullanan 20 hastada toksikolojik yan etki görülmediğini bildirmiştir. Hastaların kanındaki gümüş seviyesinin 56,6 ppb'yi (milyarda bir parça) geçmediğini, böbrek ve karaciğerde önemli bir değişiklik olmadığını ve lökopeni olmadığını ve hiçbir hastada arjiri gelişmediğini gösterdiler. Protezden salınan gümüşün lokal veya sistemik yan etkilere neden olmadığı sonucuna varmışlardır. Hardes ve ark. tarafından 2010 yılında yayımlanan bir başka klinik çalışmada ${ }^{[33]}$, tümör hastalarında \%17,6'ılk enfeksiyon oranlarının, gümüş kaplı aynı implantlarla \%5,9'a düşürülebileceğini göstermiştir. 2013 yılında yayımlanan çalışmalarında Hussmann ve ark. ${ }^{[34]}, 18$ hastada gümüşlü protez sonrası yara sıvısında ve plazmada kütle spektrometresi ile gümüş iyonu konsantrasyonunu ölçtüler. Gümüş iyonu konsantrasyonunu milyonda 0,08 parça olarak buldular. Gümüş kaplı implantların enfeksiyon oranlarını azalttığını, hastanede kalış süresini kısalttığını ve gümüşle ilgili toksik etki görmediklerini bildirdiler. Wafa ve ark.[35], 2015 yılında yayımladıkları çalışmada riskli hastalarda protez enfeksiyonunun kontrol grubunda \%22,4 iken, gümüş kaplı implantlarda yarıya, \%11,8'e indiğini bildirmiştir. Çalışmalarında 31 hastanın yedisinde lokal arjiri gelişti. İyi sonuçlar nedeniyle tüm protez revizyon olgularında ve yüksek enfeksiyon riski olan primer protez olgularında gümüş kaplı implantlar uyguladıklarını bildirmişlerdir.

2016 yılında Hua ve ark. ${ }^{[36]}$, intravenöz olarak enjekte ettikleri gümüş iyonlarından ziyade nano gümüş partiküllerinin, vasküler endotelial hücrelerde ROS (serbest/reaktif oksijen radikalleri) seviyelerine neden olduğunu ve bunun da uzun süreli organ toksisitesine yol açtığını göstermiştir.

Biz anti-enfektif özellikli metal implant kaplamaları için gümüş iyonu kullandık. Metal implantların yüzeylerini kaplamak için Ag + iyon katkılı kalsiyum fosfat 


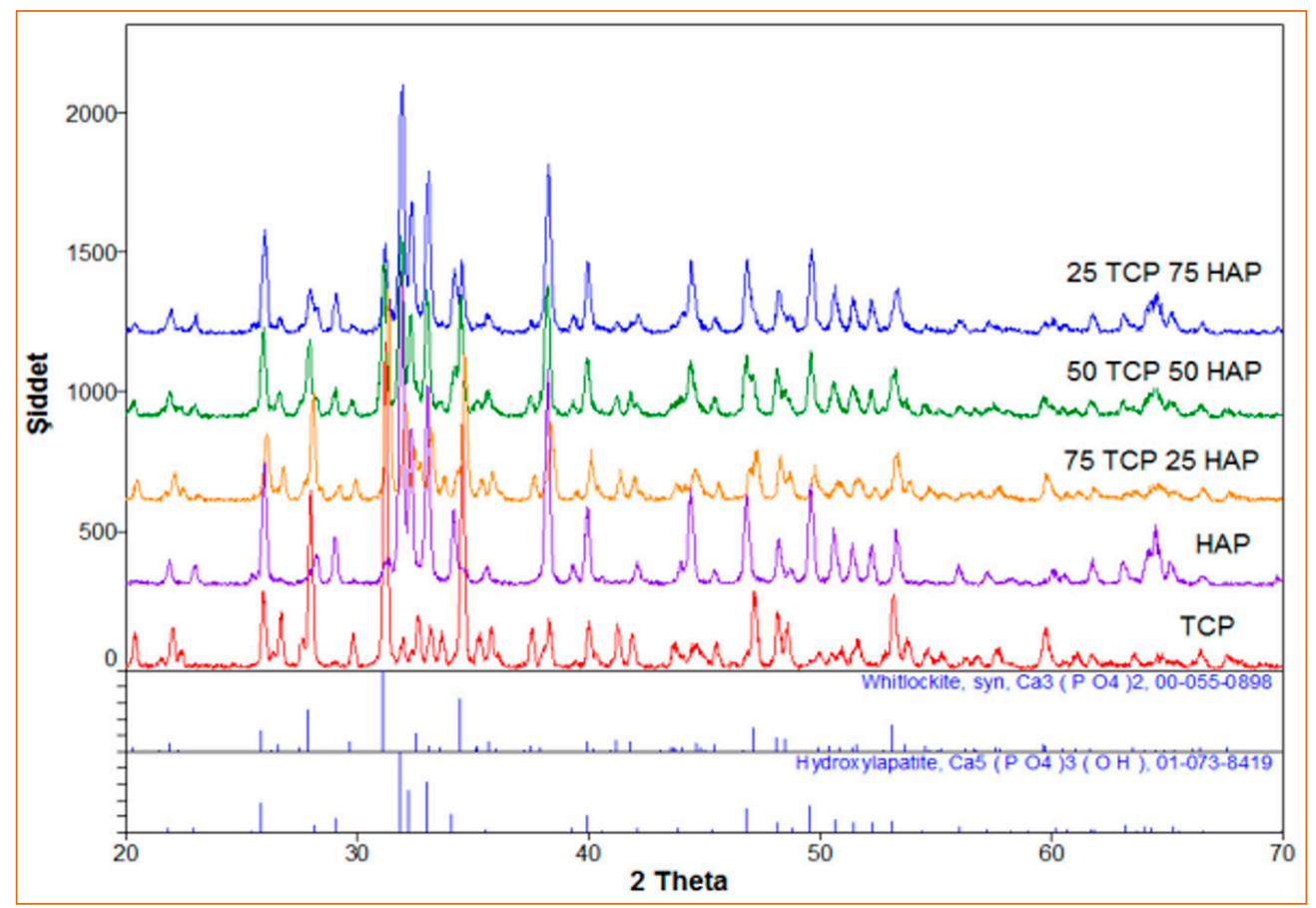

Şekil 2. XRD örgü deseninde farklı kompozisyonlarda hazırlanan HA ve TCP fazlarını göstermektedir.
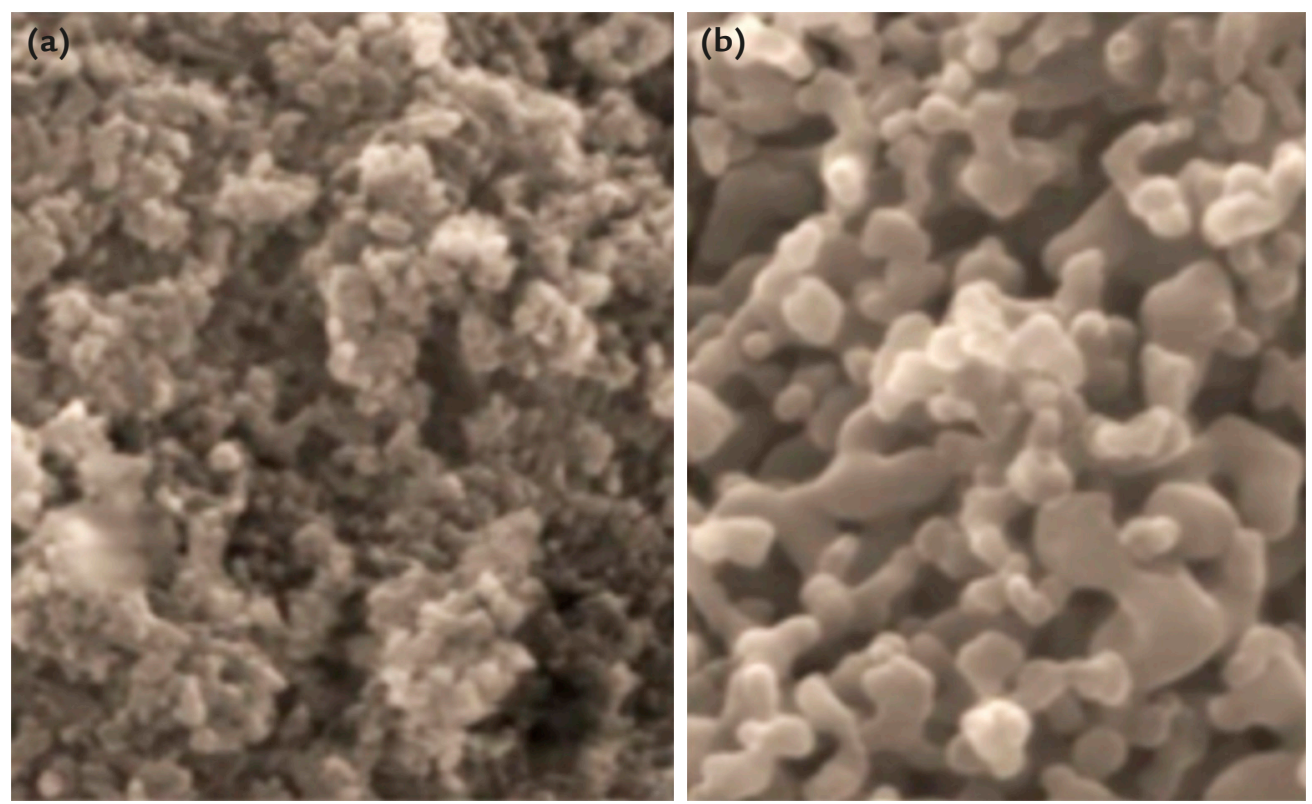

Şekil 3. a, b. Sentezden sonra (a) ve kalsinasyondan sonra HA tozu (b).

bazlı toz geliştirildi. Toz ıslak kimyasal yöntemle sentezlendi. $\left(10 \mathrm{Ca}(\mathrm{OH})_{2}+6 \mathrm{H}_{3} \mathrm{PO}_{4} \rightarrow \mathrm{Ca}_{10}\left(\mathrm{PO}_{4}\right)_{6}(\mathrm{OH})_{2}\right.$ $+18 \mathrm{H}_{2} \mathrm{O}$ ). Kalsiyum fosfat bazlı tozun faz analizi için X-ışını difraktometresi kullanıldı ve analiz, $20-80^{\circ}$ arasında $2 \%$ dakikada gerçekleştirildi. Şekil 2, sentez ve kalsinasyondan sonra tozun faz analizinin sonuçlarını göstermektedir. Metalik implantların gümüş iyon katkılı seramik nanopowder kaplaması, kaplanmamış implantlara kıyasla bakteri kolonizasyonuna karşı direncin artmasına neden oldu. ${ }^{[26-28,37]}$ Şekil 3, HA tozunun mikro-yapı görüntülerini göstermektedir. Daha sonra bu tozla yapılan kaplamaların in vitro ve hayvan çalışmalarının başarılı olması üzerine, geliştirilen antimikrobiyal kaplama klinikte gönüllü hastalar 


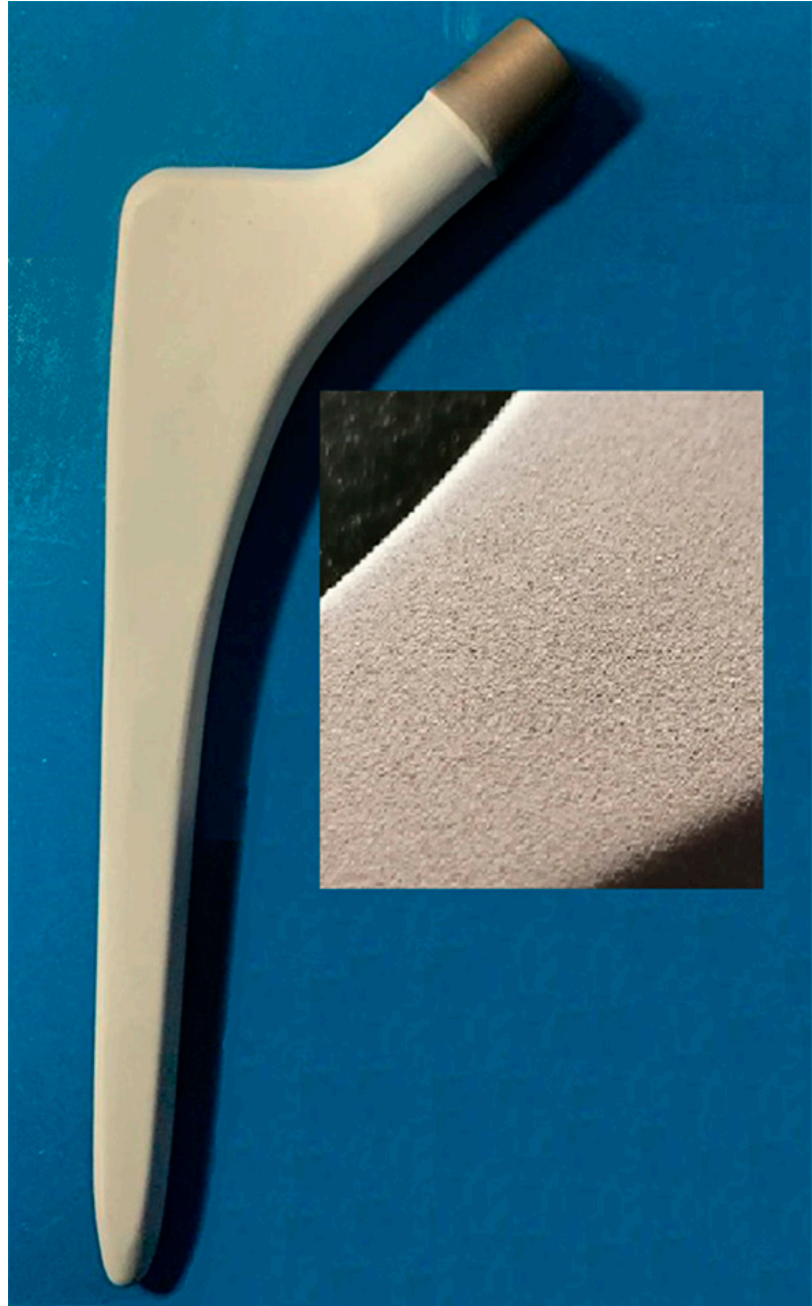

Şekil 4. Gümüş iyon katkılı seramik ile kaplanmış kalça protez sapı.

üzerinde denenmiştir (Şekil 4). Otuz altı hastada denenen bu kaplamanın ilk sonuçlarının başarılı olduğu bildirilmiştir. ${ }^{[38]}$

\section{SONUÇ}

İmplant kullanımını takiben ortopedi ve travmatoloji alanında uygulanan cerrahide bakteriyel enfeksiyon yaygın ve ciddi bir komplikasyondur. Daha uzun hastanede kalış süresi, daha yüksek maliyetler ve daha yüksek morbidite ve mortalite bildirilmiştir. İmplantla ilişkili enfeksiyonun patogenezinde biyofilm oluşumunun öneminin giderek daha fazla tanınmasıyla birlikte biyofilm oluşumu ve antibiyotik ilaç direnci problemleriyle mücadele etmek için yeni stratejiler geliştirilmiştir. Hayvan ve klinik çalışmalarımızdan elde edilen sonuçlar, implantın gümüş iyon katkılı nano-seramiklerle kaplanmasının implantlarda biyofilm oluşumunu güçlü bir şekilde inhibe ettiğini ve çevresindeki dokudaki bakteri sayısını azalttığını gösterdi. Gümüş iyon katkılı nano-seramik kaplamalar ortopedik tıbbi cihazlar için potansiyel anti-enfektif bariyer sağlar.

\section{Not}

Bu yazıdaki metnin büyük bir kısmı, editörlügü̈nü Prof. Dr. Necdet Sağlam'ın yaptığı “Presenting and treating bone infections using silver-ion containing nanohydroxyapatite" adlı yazımdan alıntı yapılmıştır.

\section{KAYNAKLAR}

1. Bethesda MD. NIH Curriculum Supplement Series, National Institutes of Health (US); Biological Sciences Curriculum Study. US: National Institutes of Health; 2007.

2. WHO. Global Guidelines for the Prevention of Surgical Site Infection. Geneva: World Health Organization; 2018.

3. Berríos-Torres SI, Umscheid CA, Bratzler DW, Leas B, Stone EC, Kelz RR, Reinke CE, Morgan S, Solomkin JS, Mazuski JE, Dellinger EP, Itani KMF, Berbari EF, Segreti J, Parvizi J, Blanchard J, Allen G, Kluytmans JAJW, Donlan R, Schecter WP; Healthcare Infection Control Practices Advisory Committee. Centers for Disease Control and Prevention Guideline for the Prevention of Surgical Site Infection. JAMA Surg 2017;152(8):784-91. Crossref [Erratum in: Crossref]

4. Sessler DI. Non-pharmacologic Prevention of Surgical Wound Infection. Anesthesiol Clin 2006;24(2):279-97. Crossref

5. Rupp M, Popp D, Alt V. Prevention of infection in open fractures: Where are the pendulums now? Injury 2019. Crossref

6. Ogbemudia AO, Bafor A, Ogbemudia EJ, Edomwonyi E. Efficacy of $1 \%$ silver sulphadiazine dressings in preventing infection of external fixation pin-tracks: a randomized study. Strategies Trauma Limb Reconstr 2015;10(2):95-9. Crossref

7. Gustilo RB, Anderson JT. Prevention of infection in the treatment of one thousand and twenty-five open fractures of long bones: retrospective and prospective analyses. J Bone Joint Surg Am 1976;58(4):453-8.

8. Teterycz D, Ferry T, Lew D, Stern R, Assal M, Hoffmeyer $P$, Bernard L, Uçkay I. Outcome of orthopedic implant infections due to different staphylococci. Int J Infect Dis 2010;14(10):e913-8. Crossref

9. Whitehouse JD, Friedman ND, Kirkland KB, Richardson WJ, Sexton DJ. The impact of surgical-site infections following orthopedic surgery at a community hospital and a university hospital: adverse quality of life, excess length of stay, and extra cost. Infect Control Hosp Epidemiol 2002;23(4):183-9. Crossref

10. Gristina AG. Biomaterial-centered infection: microbial adhesion versus tissue integration. Science 1987;237(4822):1588-95. Crossref

11. Buchholz HW, Engelbrecht $\mathrm{H}$. Depot effects of various antibiotics mixed with Palacos resins. Chirurg 1970;41(11):511-5.

12. Buttaro MA, Pusso R, Piccaluga F. Vancomycin-supplemented impacted bone allografts in infected hip arthroplasty Twostage revision results. J Bone Joint Surg Br 2005;87-B:314-9. Crossref

13. Arciola CR, Campoccia D, Montanaro L. Implant infections: adhesion, biofilm formation and immune evasion. Nat Rev Microbiol 2018;16(7):397-409. Crossref 
14. Yao Z, Lin TH, Pajarinen J, Sato T, Goodman S. Chapter 12: Host Response to Orthopedic Implants (Metals and Plastics). In: Badylak SF, editor. Host Response to Biomaterials. Elsevier, Academic Press; 2015. p.315-73.

15. Romanò CL, Scarponi S, Gallazzi E, Romanò D, Drago L. Antibacterial coating of implants in orthopaedics and trauma: a classification proposal in an evolving panorama. J Orthop Surg Res 2015;10(1):157. Crossref

16. Hetrick EM, Schoenfisch MH. Reducing implant-related infections: active release strategies. Chem Soc Rev 2006;35(9):780-9. Crossref

17. Rivardo F, Turner RJ, Allegrone G, Ceri H, Martinotti MG. Anti-adhesion activity of two biosurfactants produced by Bacillus spp. prevents biofilm formation of human bacterial pathogens. Appl Microbiol Biotechnol 2009;83(3):541-53. Crossref

18. Geesink RG, de Groot K, Klein CP. Chemical implant fixation using hydroxyl-apatite coatings. The development of a human total hip prosthesis for chemical fixation to bone using hydroxyl-apatite coatings on titanium substrates. Clin Orthop Relat Res 1987;(225):147-70. Crossref

19. Choi S, Murphy WL. Sustained plasmid DNA release from dissolving mineral coatings. Acta Biomater 2010;6(9):342635. Crossref

20. Saran N, Zhang R, Turcotte RE. Osteogenic protein-1 delivered by hydroxyapatite-coated implants improves bone ingrowth in extracortical bone bridging. Clin Orthop Relat Res 2011;469(5):1470-8. Crossref

21. Jiang W, Cheng J, Agrawal DK, Malshe AP, Liu H. Improved Mechanical Properties of Nanocrystalline Hydroxyapatite Coating for Dental and Orthopedic Implants. Adv Mater Design Regen Med 2009;1140:215-9. Crossref

22. Romanò CL, Tsuchiya H, Morelli I, Battaglia AG, Drago L. Antibacterial coating of implants: are we missing something? Bone Joint Res 2019;8(5):199-206. Crossref

23. Ewald A, Gluckermann SK, Thull R, Gbureck U. Antimicrobial titanium/silver PVD coatings on titanium. Biomed Eng Online 2006;5:22. Crossref

24. Gordon O, Slenters TV, Brunetto PS, Villaruz AE, Sturdevant DE, Otto M, Landmann R, Fromm KM. Silver coordination polymers for prevention of implant infection: thiol interaction, impact on respiratory chain enzymes, and hydroxyl radical induction. Antimicrob Agents Chemother 2010;54(10):4208-18. Crossref

25. Gosheger G, Hardes J, Ahrens $H$, Streitburger A, Buerger $H$, Erren M, Gunsel A, Kemper FH, Winkelmann W, von Eiff C. Silver-coated mega endoprostheses in a rabbit modelan analysis of the infection rate and toxicological side effects. Biomaterials 2004;25(24):5547-56. Crossref

26. Kose N, Otuzbir A, Pekșen C, Kiremitçi A, Doğan A. A silver ion-doped calcium phosphate-based ceramic nanopowdercoated prosthesis increased infection resistance. Clin Orthop Relat Res 2013;471(8):2532-9. Crossref
27. Bostancıoğlu RB, Peksen C, Genc H, Gürbüz M, Karel FB, Koparal AS, Dogan A, Kose N, Koparal AT. Analyses of the modulatory effects of antibacterial silver doped calcium phosphate-based ceramic nano-powder on proliferation, survival, and angiogenic capacity of different mammalian cells in vitro. Biomed Mater 2015;10(4):045024. Crossref

28. Kose N, Çaylak R, Pekşen C, Kiremitçi A, Burukoglu D, Koparal S, Doğan A. Silver ion doped ceramic nano-powder coated nails prevent infection in open fractures: In vivo study. Injury 2016;47(2):320-4. Crossref

29. Chen W, Liu Y, Courtney HS, Bettenga M, Agrawal CM, Bumgardner JD, Ong JL. In vitro antibacterial and biological properties of magnetron co-sputtered silver-containing hydroxyapatite coating. Biomaterials 2006;27:5512-7. Crossref

30. Secinti KD, Ayten M, Kahilogullari G, Kaygusuz G, Ugur HC, Attar A. Antibacterial effects of electrically activated vertebral implants. J Clin Neurosci 2008;15:434-9. Crossref

31. Spadaro JA, Berger TJ, Barranco SD, Chapin SE, Becker RO. Antibacterial effects of silver electrodes with weak direct current. Antimicrob Agents Chemother 1974;6(5):637-42. Crossref

32. Hardes J, Ahrens $H$, Gebert $C$, Streitbuerger A, Buerger $H$, Erren M, Gunsel A, Wedemeyer C, Saxler G, Winkelmann W, Gosheger G. Lack of toxicological side-effects in silver-coated megaprostheses in humans. Biomaterials 2007;28(18):286975. Crossref

33. Hardes J, von Eiff C, Streitbuerger A, Balke M, Budny $T$, Henrichs MP, Hauschild G, Ahrens $H$. Reduction of periprosthetic infection with silver-coated megaprostheses in patients with bone sarcoma. J Surg Oncol 2010;101(5):38995. Crossref

34. Hussmann, B. Kauther IJ, Landgraeber S, Jäger M, Lendemans $S$. Measurement of the Silver lon Concentration in Wound Fluids after Implantation of Silver-Coated Megaprostheses: Correlation with the Clinical Outcome. Biomed Res Int 2013;2013:763096. Crossref

35. Wafa H, Grimer RJ, Reddy K, Jeys L, Abudu A, Carter SR, Tillman RM. Retrospective evaluation of the incidence of early periprosthetic infection with silver-treated endoprostheses in high-risk patients: case-control study. Bone Joint J 2015;97$B(2): 252-7$. Crossref

36. Hua G, Zhang J, Boudreau M, Meng J, Yin J, Liu J, Xu H. Intravenous administration of silver nanoparticles causes organ toxicity through intracellular ROS-related loss of interendothelial junction. Part Fibre Toxicol 2016;13:21. Crossref

37. Kose N, Kose AA. Application of Nanomaterials in Prevention of Bone and Joint Infections. In: Rai M, Kon K, editors. Nanotechnology in Diagnosis, Treatment and Prophylaxis of Infectious Diseases, 1st ed. Elsevier, Academic Press; 2015. p. 107-117.

38. Köse N, Köse A, Bayrak C, Sevencan A, Akyürekli AG, Koparal $T$, Doğan A. The Use of Silver Ion Doped Calcium Phosphate Based Ceramic (Silveron $®$ ) Coated Implants for Preventing Implant Related Infection. Asya Pasifik Ortopedi Birliği Kongresi 2018 (APOA 2018). Antalya, Turkey. 